\title{
Mediterranean Spotted Fever: Retrospective Evaluation of 16 Cases
}

\author{
Akdeniz Benekli Ateşi: 16 Olgunun Retrospektif İncelenmesi \\ Emel YILMAZ, Halis AKALIN, Reşit MISTIK, Yasemin HEPER, Aynur ENGINN, ${ }^{1}$ Ebru KILIÇASLAN, \\ Aslihan ÖZTÜFEKÇİ, Emine SEVGİCAN, Safiye HELVACI, Okan TÖRE \\ Department of Infectious Diseases and Microbiology, Medical Faculty of Uludağ University, Bursa; \\ ${ }^{1}$ Department of Infectious Diseases and Microbiology, Medical Faculty of Cumhuriyet University, Sivas
}

Submitted / Başvuru tarihi: 07.11.2008 Accepted / Kabul tarihi: 13.01.2009

Objectives: Mediterranean spotted fever (MSF) is an acute febrile, zoonotic disease caused by Rickettsia conorii and endemic infectious disease in Mediterranean countries.

Patients and Methods: In this study, a retrospective examination of 16 cases ( 4 females, 12 males; mean age $38.9 \pm 13.0$; range 18 to 64 years) that were diagnosed with rickettsioses between 1987-2007 was performed. Diagnosis of MSF was based upon epidemiological and clinical features, indirect immunofluorescence antibody (IFA), as well as response to doxycycline therapy.

Results: High fever and maculopapular rash were present in all cases. Palmar and plantar rash were evident in $13(81.3 \%)$ and eschar in eight $(50 \%)$ cases. All cases responded to treatment within $2 \pm 0.9$ days, and no death was observed.

Conclusion: Mediterranean spotted fever should be considered in the differential diagnosis of all patients admitting with fever, maculopapular rash, headache and/or musclejoint pain during spring, summer and autumn. Key words: Mediterranean spotted fever; Maculopapular rash; fever.
Amaç: Rickettsia conoriỉnin neden olduğu Akdeniz benekli ateşi (ABA), Akdeniz ülkelerinde akut, endemik, zoonotik bir enfeksiyon hastalığıdır. Bu hastalık ülkemiz için endemik olduğundan sunmayı amaçladık.

Hastalar ve Yöntemler: Bu çalışmada, 1987-2007 yılları arasında riketsiyoz tanısı alan 16 olgu (4 kadın, 12 erkek; ort. yaş 38.9 \pm 13.0 ; dağılım 18-64) retrospektif olarak incelendi. Akdeniz benekli ateşi tanısı epidemiyolojik özellikleri, indirekt floresan antikor testi (IFA), hastaların klinik bulguları ve doksisiklin tedavisine verdikleri yanıta göre kondu.

Bulgular: Olguların tümünde ateş yüksekliği, makülopapüler döküntü tespit edildi. On üç (\%81.3) olguda avuç içi ve ayak tabanında döküntü; sekiz olguda (\%50) eskar tespit edildi. Tedaviye yanıt $2 \pm 0.9$ günde gelişti ve tüm olgularda tedaviye yanıt alındı.

Sonuç: Illkbahar, yaz ve sonbahar aylarında, ateş, makülopapüler döküntü, baş ağrısı ve/ veya kas-eklem ağrısı yakınmalarıyla başvuran olgularda ayırıcı tanıda mutlaka $A B A$ düşünülmelidir.

Anahtar sözcükler: Akdeniz benekli ateşi; makülopapüler döküntü; ateş.

\footnotetext{
Presented at the 12th Turkish Microbiology and Infectious Diseases Congress, November 16-20, 2005, Antalya, Turkey (12. Türk Mikrobiyoloji ve Infeksiyon Hastalıkları (KLIMIK) Kongresi'nde sunulmuştur, 16-20 Kasım 2005, Antalya).

Correspondence (IIletişim adresi): Dr. Emel Yılmaz. Uludağ Üniversitesi Tıp Fakültesi Infeksiyon Hastalıkları ve Mikrobiyoloji Anabilim Dalı, 16059

Bursa. Tel: 0224 - 2954122 Fax (Faks): 0224 - 4429181 e-mail (e-posta): emelyilmaz@uludag.edu.tr

(c) Trakya Üniversitesi Tıp Fakültesi Dergisi. Ekin Tıbbi Yayıncııı tarafından basılımıştır. Her hakkı sakııdır.

(c) Medical Journal of Trakya University. Published by Ekin Medical Publishing. All rights reserved.
} 
Mediterranean spotted fever (MSF) is an acute zoonotic infectious disease classified in the spotted fever group of rickettsioses. Spotted fever cases have frequently been reported in various parts of the world in 1970 and 1980s..$^{[1,2]}$ While Rickettsia conorii, which is transmitted by brown dog tick (Rhipicephalus sanguineus) bite, has been demonstrated as the principal etiologic agent of the spotted fever in the Mediterranean region and Southern Europe (Italy, Spain, Portugal, Greece, Turkey, Cyprus, Palestine, Romania, Bulgaria); six different new rickettsia species have been described as etiologic agents for spotted fever in Europe after 1991: Rickettsia conorii caspia, $R$. conorii israelensis, $R$. aeschlimannii, $R$. sibirica mongolotimonae, $R$. slovoca, $R$. massiliae. ${ }^{[2-4]}$ Clinical and epidemiological features of the rickettsioses cases diagnosed with MSF as well as their response to treatment have been evaluated in this study. The aim of this study was to evaluate the clinical and epidemiological features of Mediterranean spotted fever cases and their response to treatment with antimicrobial agents.

\section{PATIENTS AND METHODS}

Sixteen cases admitted to our clinic with high fever, maculopapular rash and headache between May 1987 and July 2007 and diagnosed with rickettsioses were evaluated retrospectively.

At first visit, the following laboratory values were obtained for each patient: complete blood count, blood culture, blood chemistry, transaminases, GGT, creatine kinase, lactic dehydrogenase, urine analysis, Rose Bengal, Brucella agglutination and Gruber Widal test were also obtained in clinically compatible patients. Epidemiological characteristics such as animal contact, tick bite, living or having been in the country side, clinical features such as the presence of maculopapular rash that does not fade under pressure, palmar and plantar rash, eschar (=tache noire) and laboratory findings of the cases were evaluated. Indirect immunofluorescence antibody (Rickettsia conorii- Spot IF, BioMerieux, Marcy L'Etoile, France) has been performed, as a serological test and positivity was considered when antibody titers $\geq 1 / 40$.

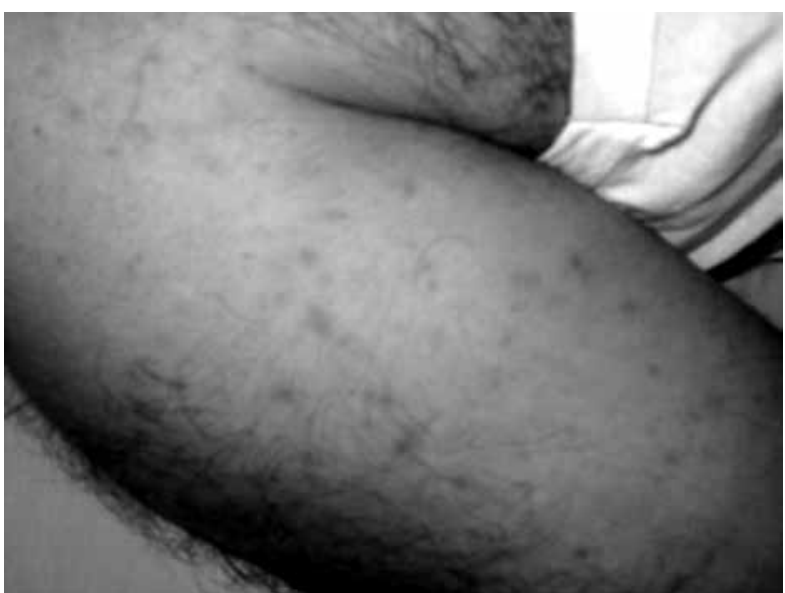

Fig. 1. Maculopapular rash in a patient diagnosed with MSF in our clinic.

The diagnosis of MSF was established according to the epidemiological and clinical features and also by the clinical response to doxycycline therapy approximately within two days. Raoult score was also used for diagnosis of the cases. ${ }^{[4-6]}$

\section{RESULTS}

Sixteen cases, aging between 18 and 64 (mean 38.9+13.0) years were diagnosed with MSF, and of those four (25\%) were women, and 12 (75\%) were men. Nine cases $(56.3 \%)$ had been admitted to our clinic in summer, three $(18.8 \%)$ in spring and four (25\%) in autumn. Eight cases (50\%) had a history of animal contact. History of tick bite was present in five cases and one case described cleaning his dog from ticks, although he did not recall an actual tick bite. All of our cases had high fever followed by a maculopapular rash observed several days later (Fig. 1). Relative bradycardia was obtained in $14(81.2 \%)$ cases and palmar and plantar rash in $13(81 \%)$. Eschar (= tache noire) was present in eight (50\%) cases (Figs. 2a, b). Regional lymphadenopathy was found in four of the cases with eschar formation. Clinical characteristics and laboratory findings of the cases have been summarized in Table 1 and 2.
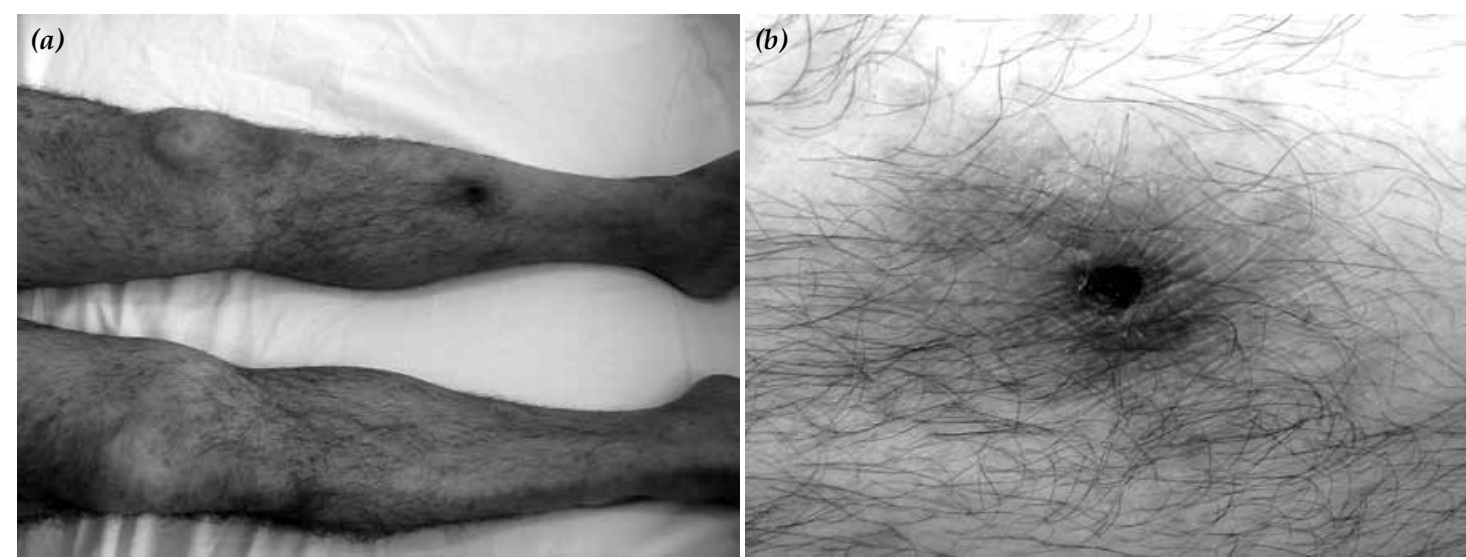

Fig. 2. (a) Eschar (= tache noire) in an MSF patient. (b) Close-up view of the eschar. 
Table 1. Symptoms and clinical characteristics in $\mathbf{1 6}$ MSF cases

\begin{tabular}{lcc}
\hline Clinical characteristics of the cases & $\mathrm{n}$ & $\%$ \\
\hline Fever & 16 & 100 \\
Maculopapular rash & 16 & 100 \\
Palmar and plantar rash & 13 & 81.3 \\
Eschar & 8 & 50 \\
Headache & 10 & 62.5 \\
Muscle/joint pain & 6 & 37.5 \\
Hepatosplenomegaly & 5 & 31.3 \\
Gastrointestinal system complaints & 4 & 25 \\
Conjunctivitis & 1 & 6.3 \\
Confusion & 1 & 6.3 \\
\hline
\end{tabular}

IFA serological test could have been performed only in four cases in acute period. While $\operatorname{IgM}$ and $\operatorname{IgG}$ were found to be positive in two cases $(1 / 40)$, IgM was negative and IgG was positive in one case whereas $\operatorname{IgM}$ and IgG were both negative in the other. Chloramphenicol therapy was started in two of the cases admitted in 1987 and 1988; doxycycline therapy was initiated in others. A response in fever was obtained following one to four days of treatment (2.0 \pm 0.9 days). For differential diagnosis, blood cultures were studied in all patients and there was no growth. The results of Raoult score for all cases were shown in Table 3. We found score between 18 and 28 (mean 22.6 \pm 1.06 ). Only six patients had Raoult score $>25$.

\section{DISCUSSION}

Since Rickettsia are obligate intracellular bacteria, their isolation is rather difficult. Diagnosis of MSF can be accomplished by patient complaints and clinical signs as well as using more specific and sensitive tests such as indirect immunofluorescence antibody (IFA) test, indirect immunoperoxidase, latex agglutination and enzyme-linked immunosorbent assay (EIA). Serological tests become positive after the second week of the disease. Therefore, prompt treatment should be initiated in cases suspected of rickettsioses based on patient history and clinical evidences. ${ }^{[4-9]}$

A comparison of complaints and evidences encountered in our patients with those observed in the other studies has been summarized in Table 4 .

Most of the cases reported in the literature have been observed between April and October. Nine of the cases in our series have been admitted to our clinic in summer, three in spring and four in autumn. Also, in accordance with the previous reports, fever and maculopapular rash were present in all of our cases (Table 4). The frequencies of observing palmar and plantar rash (81.3\%) were comparable with the values reported by Raoult et al. ${ }^{[10]}$ and Kuloğlu et al. ${ }^{[3]}$ (79\% and $80 \%$ respectively) but Mert et al. ${ }^{[1]}$ had observed a lower frequency (33\%). Additionally, headache and muscle/joint pain were
Table 2. Laboratory results of 16 MSF cases

\begin{tabular}{lcc}
\hline Laboratory results of the cases & $\mathrm{n}$ & $\%$ \\
\hline Leukocytosis $\left(>10000 / \mathrm{mm}^{3}\right)$ & 5 & 31.3 \\
Leukopenia $\left(<5000 / \mathrm{mm}^{3}\right)$ & 2 & 12.5 \\
Anemia $(\mathrm{Hb}<11 \mathrm{~g} / \mathrm{dL})$ & 1 & 6 \\
Thrombocytopenia $\left(<150000 / \mathrm{mm}^{3}\right)$ & 5 & 31.3 \\
AST and/or ALT elevation $(>50 \mathrm{IU} / \mathrm{L})$ & 12 & 75 \\
LDH elevation $(>250 \mathrm{IU} / \mathrm{L})$ & 7 & 43 \\
ESR elevation $(>20 \mathrm{~mm} / \mathrm{h})$ & 14 & 87 \\
\hline
\end{tabular}

AST: Aspartate aminotransferase; ALT: Alanine aminotransferase; LDH: Lactic dehydrogenase; ESR: Erythrocyte sedimentation rate.

reported as more common ( $87 \%$ and $93 \%$ respectively) among the cases followed by Mert et al., ${ }^{[1]}$ compared to the lower frequencies reported by the other studies as well as the present study (Table 4).

A characteristic lesion with a black necrotic center surrounded by a reddish purple ring called "eschar" may develop at the point of the tick bite. The lesion itself is painless; however, painful enlargement of the lymph nodes around the lesion might be observed. Eschar formation may not occur if the tick is in the larva or nymph stages. ${ }^{[2]}$ Varying prevalence of eschar formation have been reported in different series; including $84 \%$ by Antón et al., ${ }^{[11]} 72 \%$ by Raoult et al., ${ }^{[10]} 63.4 \%$ by Colomba et al., ${ }^{[12]} 33 \%$ by Kuloğlu et al., ${ }^{[3]}$ and $13 \%$ by Mert et al., ${ }^{[1]}$ while it was observed in $50 \%$ of our cases.

In accordance with the results of previous publications, thrombocytopenia was present in one third of our cases. ${ }^{[1,10]}$ AST elevation was reported as $77 \%$ by Kuloğlu et al., ${ }^{[3]} 60 \%$ by Mert et al., ${ }^{[1]} 39 \%$ by Raoult et al., ${ }^{[10]}$ and was noted in $75 \%$ of the cases in our study.

Table 3. The results of Raoult score for cases (except bacteriological and serological criteria)

\begin{tabular}{cc}
\hline Patient no & Raoult Score \\
\hline 1 & 19 \\
2 & 28 \\
3 & 27 \\
4 & 18 \\
5 & 18 \\
6 & 28 \\
7 & 19 \\
8 & 20 \\
9 & 27 \\
10 & 26 \\
11 & 25 \\
12 & 18 \\
13 & 25 \\
14 & 27 \\
15 & 19 \\
16 & 18 \\
\hline
\end{tabular}


Mediterranean Spotted Fever: Retrospective Evaluation of 16 Cases

Table 4. A comparison of the followed MSF cases in the present study with MSF cases in the previous studies

\begin{tabular}{|c|c|c|c|c|c|c|}
\hline Clinical characteristics & Raoult et al. ${ }^{[9]}$ & Anton et al. ${ }^{[10]}$ & Colomba etal..$^{[11]}$ & Mert et al. ${ }^{[1]}$ & Kuloğlu et al. ${ }^{[3]}$ & Our study \\
\hline & $(\mathrm{n}=199)(\%)$ & $(\mathrm{n}=144)(\%)$ & $(\mathrm{n}=415)(\%)$ & $(\mathrm{n}=14)(\%)$ & $(\mathrm{n}=30)(\%)$ & $(\mathrm{n}=16)(\%)$ \\
\hline Fever & 100 & 100 & 93 & 100 & 100 & 100 \\
\hline Maculopapular rash & 96 & 96 & 94.5 & 100 & 100 & 100 \\
\hline Palmar and plantar rash & 79 & - & & 33 & 80 & 81.3 \\
\hline Eschar & 72 & 84 & 63.4 & 13 & 33 & 50 \\
\hline Headache & 56 & 76 & 29.4 & 87 & 63 & 62.5 \\
\hline Muscle/joint pain & 36 & 79 & 38.1 & 93 & 27 & 37.5 \\
\hline Thrombocytopenia $<150000 / \mathrm{mm}^{3}$ & 35 & 16.7 & 13 & 33 & 47 & 31.3 \\
\hline Leukopenia $<5000 / \mathrm{mm}^{3}$ & 20 & 23 & 27.5 & 13 & 23 & 12.5 \\
\hline Leukocytosis $>10000 / \mathrm{mm}^{3}$ & 28 & 11.8 & 11.1 & 74 & 37 & 31.3 \\
\hline Elevated AST>50 IU/L & 39 & 60 & 21 & 60 & 77 & 75 \\
\hline
\end{tabular}

The course of MSF is not always benign. It may be severe in the individuals with diabetes mellitus, G6PDH (glucose 6 phosphate dehydrogenase) deficiency, chronic liver disease, and those who are alcoholic and old..$^{[1,9,13]}$ Mortality rate can be reduced to less than $5 \%$ by appropriate treatment. In the study of Raoult et al., ${ }^{[10]}$ severe disease course was experienced in 12 cases $(6 \%)$ and five patients $(2.5 \%)$ died, four of which were over 60 years of age and one had G6PDH deficiency. No complications were encountered in the followed cases in this study.

Serologic tests should be repeated, since they can be negative in early disease. However, clinical suspicion is sufficient to initiate a treatment. Rash, fever, headache, animal contact, tick bite should be questioned and by keeping in mind that serological evidence will not be present before the second week of the disease, treatment should be started..$^{[2,4,9]}$ In our cases, diagnosis was made based on epidemiological features as well as the clinical and laboratory evidences. IFA test could be performed only in four of our cases. IgM and IgG were determined to be positive in two cases, IgM was negative and IgG was positive in one case whereas IgM and IgG were both negative in the other. In the case that was negative for both IgM and IgG, IFA test was probably performed at an early stage of disease.

Doxycycline, tetracycline, chloramphenicol or fluoroquinolones are among the drugs that can be used in the treatment. ${ }^{[2,11]}$ Chloramphenicol treatment was started in two of our MSF cases and doxycycline treatment was initiated in all of the others. Fever response was observed within one to four days ( $2.0 \pm 0.9$ days) following initiation of antibiotic treatment. Antón et al. ${ }^{[1]}$ have reported that this response was observed in a mean of 2.15 days (SD 1.12) in their cases.

It has been stated in tick-related studies that tick species prefer certain environmental conditions and their geographical distribution corresponds to risk zones for tick-borne diseases. ${ }^{[2,14]}$ A total of 32 different tick species have been determined in Turkey by Karaer et al. ${ }^{[15]}$
The tick species living in our region, Marmara Region, are Ixodes ricinus, Boophilus annulatus, Hyalomma marginatum, Hyalomma anatolicum anatolicum, Hyalomma anatolicum excavatum, Hyalomma detritum, Hyalomma aegypticum, Dermacentor marginatus, Haemaphysalis numidiana, Haemaphysalis sulcata, Haemaphysalis parva, Haemaphysalis inermis, Haemaphysalis punctata, Rhipicephalus sanguineus, Rhipicephalus bursa and Rhipicephalus turanicus. ${ }^{[16]}$ The fact that Rhipicephalus sanguineus ticks, which play a role in the transmission of $R$. conorii, can be encountered in our region signifies the risk for Mediterranean spotted fever.

Vural et al. ${ }^{[14]}$ have screened human serum samples in the Antalya region of Turkey and found $R$. conorii prevalence as $13.3 \%$. They have collected 15 ticks for investigational purposes in the same region out of which 13 were identified as Ixodes ricinus, one as Dermacentor niveus, and one as Haemaphysialis sulcata.

This article presents the epidemiological and clinical features of MSF and draws the attention of clinicians to the importance of MSF in the differential diagnosis of patients with clinical signs of fever, headache, rash and specially palmar and plantar rash in the presence of epidemiological criteria according to Raoult et al.'s $\mathrm{s}^{[5]}$ diagnostic score. However, our study has a limitation. The IFA serological test could not be performed in all patients before and after therapy and thus, the changes in antibody titres could not be demonstrated.

We recommended that all suspected patients should be screened by Raoult Diagnostic Criteria and should be performed by IFA tests. We believe that, total 18 points or more (except serological and bacteriological criteria) according to Raoult Diagnostic Criteria is enough for empirical treatment in our region.

In conclusion; MIF is an endemic disease in Turkey. Therefore, this disease should be considered when a patient is admitted with fever, maculopapular rash, headache, myalgia and/or arthralgia, especially in summer, spring, and autumn. Doxycycline should be con- 
sidered as a first line choice in treatment. The rapid response to doxycycline therapy could be valuable in the differential diagnosis.

\section{REFERENCES}

1. Mert A, Ozaras R, Tabak F, Bilir M, Ozturk R. Mediterranean spotted fever: a review of fifteen cases. J Dermatol 2006;33:103-7.

2. Walker DH, Raoult D. Rickettsia rickettsii and other spotted fever group Rickettsiae (Rocky mountain spotted fever and other spotted fevers). In: Mandell GL, Bennett JE, Dolin $\mathrm{R}$, editors. Mandell, Douglas, and Bennett's principles and practice of infectious diseases. 6th ed. Philadelphia: Elsevier/Churchill Livingstone; 2005. p. 2287-95.

3. Kuloglu F, Akata F, Tansel O, Gürcan S, Otkun M, Tugrul M. Son altı yılda Trakya bölgesindeki benekli ateş grubu riketsiyoz olgularının özellikleri. Klimik Dergisi 2004; 17:87-90.

4. Brouqui P, Parola P, Fournier PE, Raoult D. Spotted fever rickettsioses in southern and eastern Europe. FEMS Immunol Med Microbiol 2007;49:2-12.

5. Raoult D, Tissot Dupont H, Caraco P, Brouqui P, Drancourt M, Charrel C. Mediterranean spotted fever in Marseille: descriptive epidemiology and the influence of climatic factors. Eur J Epidemiol 1992;8:192-7.

6. Brouqui P, Bacellar F, Baranton G, Birtles RJ, Bjoërsdorff A, Blanco JR, et al. Guidelines for the diagnosis of tickborne bacterial diseases in Europe. Clin Microbiol Infect 2004;10:1108-32.

7. Ceylan N. Riketsiyalar ve riketsiya hastalıkları. In: Eraksoy $\mathrm{H}$, Yenen OŞ, editörler. İnfeksiyon hastalıkları ve klinik mikrobiyoloji. İstanbul: Klinik Mikrobiyoloji ve İnfeksiyon Hastalıkları Derneği Yayınları; 2000. p. 293-300.

8. Tzianabos $\mathrm{T}$, Anderson BE, McDade JE. Detection of Rickettsia rickettsii DNA in clinical specimens by using polymerase chain reaction technology. J Clin Microbiol 1989;27:2866-8.

9. Yagupsky P. Mortality in serologically unconfirmed Mediterranean spotted fever. J Infect Dis 2000;181:809-12.

10. Raoult D, Weiller PJ, Chagnon A, Chaudet H, Gallais H, Casanova P. Mediterranean spotted fever: clinical, laboratory and epidemiological features of 199 cases. Am J Trop Med Hyg 1986;35:845-50.

11. Antón E, Font B, Muñoz T, Sanfeliu I, Segura F. Clinical and laboratory characteristics of 144 patients with mediterranean spotted fever. Eur J Clin Microbiol Infect Dis 2003;22:126-8.

12. Colomba C, Saporito L, Polara VF, Rubino R, Titone L. Mediterranean spotted fever: clinical and laboratory characteristics of 415 Sicilian children. BMC Infect Dis 2006;6:60.

13. de Sousa R, Nóbrega SD, Bacellar F, Torgal J. Mediterranean spotted fever in Portugal: risk factors for fatal outcome in 105 hospitalized patients. Ann N Y Acad Sci 2003;990:285-94.

14. Vural T, Ergin C, Sayin F. Investigation of Rickettsia conorii antibodies in the Antalya area. Infection 1998;26:170-2.

15. Karaer Z, Yukarı BA, Aydın L. Türkiye keneleri ve vektörlükleri. In: Özcel MA, Daldal N, editors. Parazitolojide artropod hastalıkları ve vektörler. İzmir: Türkiye Parazitoloji Derneği Yayınları, No: 13; 1997. p. 363-434.

16. Aydın L. Güney Marmara Bölgesi ruminantlarında görülen kene türleri ve yayılışları. [Doktora tezi] Bursa: U.Ü. Sağlık Bilimleri Enstitüsü; 1994. 